\title{
Isolation, Identification and Antibacterial Activity of Endophytic Bacteria from Leaves of Acacia catechu
}

\author{
Swathi Soman ${ }^{1}$, R.K. Sharma ${ }^{1 *}$, Varsha Sharma ${ }^{2}$, Vidhi Gautam², K. Shrman², Alka Sawarkar ${ }^{3}$, \\ Rituraj Kewat ${ }^{3}$ and Manish Kumar ${ }^{3}$ \\ ${ }^{1}$ Department of Veterinary Pharmacology and Toxicology, College of Veterinary Science and Animal Husbandry, NDVSU, \\ Jabalpur (M.P.), INDIA \\ ${ }^{2}$ Department of Veterinary Microbiology, College of Veterinary Science and Animal Husbandry, NDVSU, Jabalpur (M.P.), INDIA \\ *Corresponding author: RK Sharma; E-mail: drrksvet2012@gmail.com
}

Received: 28 Feb., 2020

Revised: 28 March, 2020

Accepted: 08 April, 2020

\begin{abstract}
Drug resistance in bacteria is becoming an alarming problem in recent years. Post-antibiotic era is not so far. The need for novel antibiotics, chemotherapeutic agents and agrochemicals are utmost. Endophytes are microorganisms that reside in the tissues of living plants which are relatively unstudied and are potential sources of novel natural products for exploitation in medicine, agriculture and industry. The endophytes of medicinal plants participate in biochemical pathways and produce novel bioactive compounds. The aim of the study was to isolate, identify and to assess antibacterial activity of endophytic bacteria from leaves of Acacia catechu. 18 endophytic bacteria had been isolated and identified by sequencing 16S rRNA gene. The isolated endophytic bacteria were identified as Bacillus humi. Considerable in vitro antibacterial activities against a panel of human pathogenic microorganisms (Staphylococcus aureus, Streptococcus pyogenes, Bacillus cereus, Klebsiella pneumoniae, Salmonella Typhimurium and Escherichia coli) were recorded. Among 18 isolates, 15 isolates had shown inhibitory activity against Staphylococcus aureus and Salmonella Typhimurium and 10 isolates had shown inhibitory activity against Klebsiella pneumoniae.
\end{abstract}

Keywords: Acacia catechu, endophytic bacteria, 16S rRNA gene, Bacillus humi

Antibiotic resistant bacteria have become increasing worldwide. Antibiotic resistant is defined as the reduction of effectiveness of an antibiotic during treatment of infectious diseases. Gram-negative bacteria are more resistant than Gram- positive bacteria due to presence of outer lipopolysaccharide membrane in their cell wall which limits access of antibiotic into their targets in the bacterial cells. Other mechanisms that contribute to antibiotic resistance in bacteria include modification of antibiotic target site (Aravamuthan et al., 2010). However, the discovery of new antimicrobial compounds either from natural products has declined over the years and have come to a standstill compared to the Golden Antibiotic Age (1940-1960). Endophytic bacteria are ubiquitous in most plant species, either through their active colonization of plant tissues or their latent residence. Endophytes have recently been defined as microorganisms that can be isolated from surface-disinfected plant tissues and that do not visibly harm the plant (Hallmann et al. 1997). Many endophytes have antimicrobial activity. Seo et al. (2010) found that some endophytic bacteria isolated from young radishes can be used as biocontrol agents against human and plant pathogens.

The importance of endophytes had been demonstrated over a long period as a source of pharmaceutical bioactive compounds, as many of endophytes were exposed to produce novel bioactive metabolites such as

How to cite this article: Soman, S., Sharma, R.K., Sharma, R.K., Gautam V., Shrman, K., Sawarkar, A., Kewat, R. and Kumar, M. (2020). Isolation, identification and antibacterial activity of endophytic bacteria from leaves of Acacia catechu. J. Anim. Res., 10(3): 397-403. Source of Support: None; Conflict of Interest: None क्? 
antibacterial, antifungal, antiviral, antitumor, antioxidant, anti-inflammatory, immunosuppressive drugs and many related compounds. Endophytes are well known for the production of various classes of natural products and have been reported to exhibit a broad range of biological activity and are grouped into various categories, which include alkaloids, terpenoids, steroids, lactones, phenolic compounds, quinones, lignans, etc.

Importantly, secondary metabolites produced by endophytes provide a variety of fitness enhancements and exert several beneficial effects on host plants, such as stimulation of plant growth, nitrogen fixation and induce resistance to drought, herbivorous, parasitism etc. and as sources of novel biologically active secondary metabolites. Endophytes enter the plant tissue chiefly through the root zone; on the other hand, above ground portions of plants, may also be used for entry, such as cotyledons, stems, and flowers (Rosales et al., 2017).

Acacia catechu is a small or medium -sized thorny tree upto $15 \mathrm{~m}$ tall. It belongs to Fabaceae family and subfamily Mimosoideae. The plant has diverse pharmacological actions. The phytoconstituent isolated from various parts of plant include flavanoids (catechin, epicatechin, epigallocatechin, rocatechin, quercetin), alkaloids (kaempferol, taxifolin), tannins (gallic acid, phlobatannins) and sugars ( d-galactose, d-rhamnose). Acacia catechu is one such plant showing multifarious medicinal properties viz. anti-bacterial, antioxidant, antipyretic, anti-diarrhoeal, anti-inflammatory and wound healing (Yadav et al., 2014). Various investigators reported endophytic microbes from various plant exists in different ecosystems. Consequently, the opportunity to find new and interesting microorganism among myriads of plants in different ecosystems is great. Previously, numerous reports showed on diversity of endophytic bacteria, fungi in medicinal plants (Strobel et al., 2004), but from available literature there is no report on endophytic bacteria from Acacia catechu particularly in India.

\section{MATERIALS AND METHODS}

The research was carried out in the Department of Veterinary Pharmacology and Toxicology, College of Veterinary Science and Animal Husbandry, N.D.V.S.U., Jabalpur (M.P.).

\section{Collection and sterilization of Acacia catechu leaves}

Fresh leaves of Acacia catechu were procured from Tropical Forest Research Institute campus, Jabalpur, M.P. Mature healthy plant leaves were collected. Eighteen leaves samples were taken and separated for further isolation of endophytic bacteria. Samples were immediately brought to laboratory and were used within $24 \mathrm{hrs}$ and finally processed for isolation of endophytic bacteria. The leaves were surface sterilized with $0.1 \%$ sodium hypochlorite for 5 minutes, $0.01 \%$ Bavistin, 0.05\% streptomycin, 70\% ethanol, followed by five times rinses in double distilled water for 5 minutes. Leaves were dried in laminar flow (Mahajan et al., 2014).

\section{Sterility check}

To confirm that the surface of leaves were effectively sterilized, $1 \mathrm{ml}$ of the sterile distilled water that was used in final rinse of surface sterilization procedures were plated on to nutrient agar media and incubated at $37^{\circ} \mathrm{C}$ for $24 \mathrm{hrs}$. Bacterial growths were observed after $24 \mathrm{hrs}$.

\section{Preparation and sterilization of media}

King's B (KB) media (HiMedia, India), Mueller Hinton media (HiMedia, INdia), Blood agar media (HiMedia, India) and BHI broth (HiMedia, INdia) were prepared by adding agar into the distilled water. Hot plate was used for the proper mixing of media and autoclaved at $121^{\circ} \mathrm{C}$ for $15-20$ minutes at $15 \mathrm{lbs}$.

\section{Inoculation of leaves and isolation of endophytic bacteria}

The media were poured into different autoclaved Petri plates and leaves of the plants were embedded in Petri plates. These plates were then incubated at $37^{\circ} \mathrm{C}$ for 24 hrs. Characterization of the bacteria was done according to its morphology and by Gram's staining. After that a single colony was transferred into BHI broth and incubated at $37^{\circ} \mathrm{C}$ for 24 hours.

\section{Purification of endophytic bacteria}

For purification of endophytic bacteria, subculturing was mainly done by streaking a loop full of BHI broth on the 
fresh pre solidified blood agar plates and then incubated at $37^{\circ} \mathrm{C}$ for $24 \mathrm{hrs}$. After incubation the colony was transferred into BHI broth and then incubated at $37^{\circ} \mathrm{C}$ for 24 hrs and purity was checked by Gram's staining and stored for further work.

\section{Characterization of endophytic bacteria}

The characterization was done on the basis of staining, morphological, biochemical and molecular methods.

\section{Staining}

Gram's staining was done where thin smears of obtained cultures were prepared on separate glass slides, air dried and heat fixed. Each smear was covered with crystal violet and allowed to stand for 1 minute followed by washing with distilled water. Further Gram's iodine was added and allowed to stand for 1 minute. Decolourized with $95 \%$ ethyl alcohol and the slide was rinsed with distilled water. Slide was flooded with safranin to counterstain and allowed to stand for 1 minute. Smear was rinsed with distilled water and dried with absorbent paper. Slides were then observed at $100 \mathrm{X}$.

\section{Morphological characterization}

Form, elevation, margin, surface, opacity and chromogenesis of isolated endophytic bacterial colonies were noted for morphological characterization.

\section{Biochemical characterization}

Various biochemical tests like catalase (Slide method), coagulase (Tube method), Voges-Proskauer, ONPG, urease, arginine utilization and sugar fermentation tests (Hi media Identification test kit) were performed.

\section{Molecular characterization}

DNA isolation - An overnight grown isolated endophytic bacterial colony were picked and resuspended it in $1 \mathrm{ml}$ of autoclaved water in a microfuge tube. Later centrifuged for one minute at 10,000-12,000 rpm. Supernatant was removed and $200 \mu \mathrm{l}$ of Instagene matrix was added to the pellet and incubated at $56^{\circ} \mathrm{C}$ for $15-30$ minutes. Centrifuged pellet was vortexed for 10 seconds and then tube was placed in a $100^{\circ} \mathrm{C}$ boiling water bath for 8 minutes. Vortexed at high speed for 10 seconds. Spinned at 10,000-12,000 rpm for 2-3 minutes. Finally isolated DNA was stored at $-20^{\circ} \mathrm{C}$ till further use.

To perform molecular identification of bacteria, marker gene for 16S rRNA was used. The PCR used universal primers $\quad 8 \mathrm{~F} \quad$ (5'AGAGTTTGATCCTGGCTCAG3') and 1541R (5'AAGGAGGTGATCCAGCCGCA3') to amplify approximately 1500 bp of $16 \mathrm{~S}$ rRNA gene (Edward et al., 1989).

\section{PCR reaction mixture}

Readymix Taq Master mix with $\mathrm{MgCl}_{2}$ (Himedia) was used to prepare PCR reaction mixture. In a PCR TUBE, $25 \mu 1$ reaction mixture was prepared as follows:

\begin{tabular}{ll}
\hline Components & Quantity \\
\hline Taq Master mix & $12 \mu \mathrm{l}$ \\
Forward primer & $1.5 \mu 1$ \\
Reverse primer & $1.5 \mu \mathrm{l}$ \\
DNA & $5 \mu \mathrm{l}$ \\
Deionized water & $5 \mu \mathrm{l}$ \\
\hline Total & $\mathbf{2 5} \boldsymbol{\mu l}$ \\
\hline
\end{tabular}

Mixed gently and briefly centrifuged to collect all components to the bottom of the tube. The PCR tubes with all the components were then transferred to thermal cycler (Bio-Rad laboratories Inc. USA). The PCR protocol designed for 25 cycles is as follows and was kept same for all the primers used.

\section{PCR amplification conditions}

Initial denaturation step at $95^{\circ} \mathrm{C}$ for 2 min., 25 cycles of denaturation at $95^{\circ} \mathrm{C}$ for $30 \mathrm{~s}$, annealing at $55^{\circ} \mathrm{C}$ for $30 \mathrm{~s}$, extension at $72^{\circ} \mathrm{C}$ for $2 \mathrm{~min}$, followed by final extension step at $72^{\circ} \mathrm{C}$ for $10 \mathrm{~min}$.

\section{Agarose Gel Electrophoresis of PCR products}

The PCR products were tested for amplification of specific gene by agarose gel electrophoresis using 2.0 per cent agarose gel in $1 \mathrm{x}$ Tris Borate EDTA Buffer (Sigma-Aldrich, U.S.A.). A total volume of $35 \mathrm{ml}$ of 2.0 per cent agarose (Sigma-Aldrich, U.S.A.) was prepared in 1x Tris Borate EDTA Buffer and placed in microwave oven until melted. 
Molten agarose was allowed to cool to about $55^{\circ} \mathrm{C}$ and ethidium bromide was added to give a final concentration of $0.5 \mu \mathrm{g} / \mathrm{ml}$. The gel was poured on to electrophoresis trough fitted with comb. The gel was allowed to set on a flat surface for about 15 minutes. Electrophoresis trough was placed in an electrophoresis tank filled with 1x Tris Borate EDTA Buffer. Samples were prepared on a parafilm by mixing $1 \mu 1$ of Gel Loading Buffer (Sigma- Aldrich, U.S.A.) and $5 \mu \mathrm{l}$ of PCR products. Prepared samples were then loaded in parallel with $100 \mathrm{bp}$ ladder (Direct load PCR 100 bp low ladder, Sigma- Aldrich, U.S.A.). Electrophoresis was done at 70 volts for 10 minutes, then at 50 volts for 2 hour. Gel was viewed under a UV Transilluminator and photographed with gel documentation system (BIO RAD Gel Doc EZ Images) for future analysis. PCR products were purified using Montage PCR clean up kit (Millipore).

Data sequencing was done at Triyat Genomics, Nagpur, Maharashtra. Sequencing results were compared with existing sequences using Basic Local Alignment Search Tool program on National Centre for Biotechnology Information site (www.ncbi.nlm.nih.gov) to obtain the homology. The program MUSCLE 3.7 was used for multiple alignments of sequences. Finally, the program PhyML 3.0 aLRT was used for phylogeny analysis and HKY85 as substitution model.

\section{Antibacterial assay}

In vitro antibacterial activity of endophytic bacteria isolated from Acacia nilotica were studied. Various known pathogenic bacterial cultures viz. Escherichia coli (ATCC 25922), Klebsiella pneumoniae (ATCC 700603), Salmonella Typhimurium (ATCC 13311), Bacillus cereus (ATCC 11778), Staphylococcus aureus (ATCC 6538) and Streptococcus pyogenes (ATCC 12386) were procured from Hi media. Mc-Farlands Nephelometer was used for the determination of concentration of known culture as described by Henric et al. (1956). $1 \mathrm{ml}$ of known culture containing $3.0 \times 10^{9} \mathrm{cfu} / \mathrm{ml}$ as determined by McFarlands Nephelometer was used for antibacterial activity of endophytic bacteria. For determination of antibacterial activity of endophytic bacteria, broths were centrifuged at $4^{\circ} \mathrm{C}$ at $12000 \mathrm{rpm}$ for 30 minutes. Supernatant of each of these broths were taken, sterile disc were soaked in these broths in a sterile test tubes for $24 \mathrm{hrs}$ and dried in laminar flow. After drying the discs were used immediately for disc impregnation in the inoculated plates as described by Kirubaharan et al. (1999) with slight modifications. Ciprofloxacin discs were used as control drug to compare the effect of treatment during in vitro study. The prepared bacterial inoculums were evenly spread on a sterile Mueller Hinton agar plate as per method described by Bauer et al. (1969). The known antibiotic Ciprofloxacin (Ci) disc was simultaneously placed as a control for antibiotic sensitivity. The dried disc was incubated at $37^{\circ} \mathrm{C}$ for $24 \mathrm{hrs}$. Results were recorded as positive (growth) or negative (no growth) and zone of inhibition of growth exerted by these impregnated discs.

\section{RESULTS AND DISCUSSION}

\section{Isolation of endophytic bacteria}

A total 18 isolates of endophytic bacteria were obtained and were characterized using gram's staining (Fig. 1).

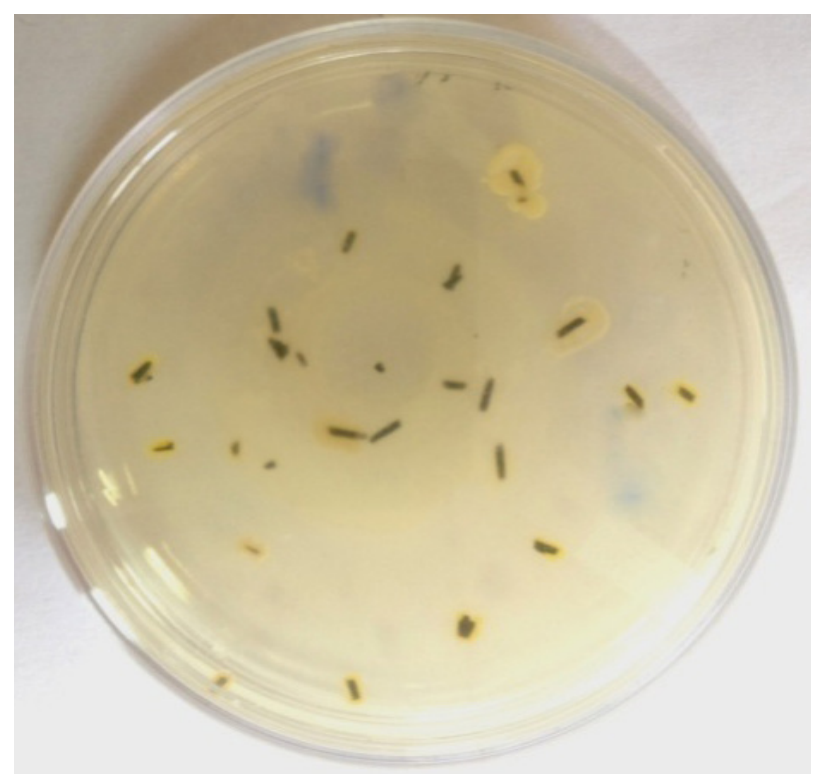

Fig. 1: Growth of endophytic bacteria from leaves of Acacia catechu on King's B media

\section{Gram's staining}

Endophytic bacteria isolated from leaves of Acacia catechu showed that 100 per cent isolates were gram positive and were found to be rods (Fig. 2). 


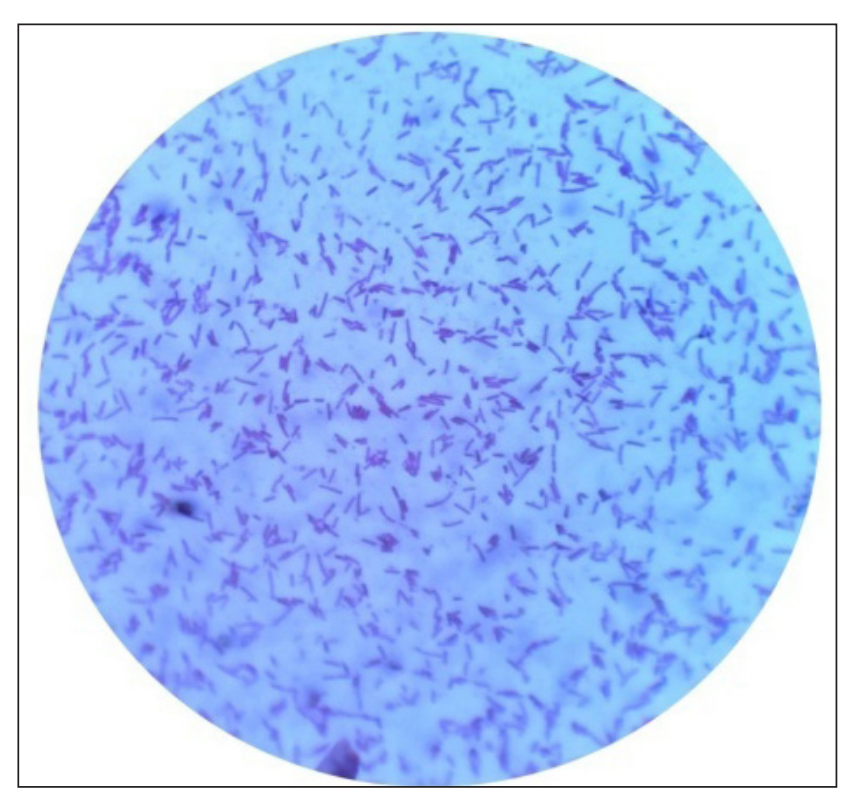

Fig. 2: Light microscopic view of endophytic bacteria isolated from Acacia catechu after Gram's staining

\section{Morphological characterization}

Growth characteristics of endophytic bacteria isolated from Acacia catechu from T.F.R.I campus showed that 84 per cent were irregular in shape while 16 per cent circular in shape, 89 per cent were flat elevation on petriplate while
11 per cent were raised elevation, margin of 67 per cent colonies were entire while 33 per cent were undulated, the surface of the growth was smooth for the entire colonies and 96 per cent growth were opaque and white in colour (Table 1).

\section{Biochemical characterization}

The endophytic bacteria isolated from Acacia catechu had shown positive reaction to catalase and sugar fermentation test (maltose) and negative reaction to coagulase, VP, ONPG, urease and arginine utilization tests. The phenetic characterization and biochemical profiling indicated the presence of endophytic bacteria in the leaves of Acacia catechu.

\section{Molecular characterization}

Endophytic bacteria were identified by comparing $16 \mathrm{~S}$ rRNA gene sequences obtained from bacterial isolates and those deposited in (NCBI) GenBank database using BLAST tool to obtain the sequences that displayed maximum similarity. Results of this analysis showed that one given sequence was actually similar to those sequences of more than one species. The amplified PCR products were run on agarose gel electrophoresis using 2.0 per cent agarose gel in 1x Tris Borate EDTA Buffer, where the

Table 1: Growth of endophytic bacteria isolated from leaves of Acacia catechu on King's B media

\begin{tabular}{|c|c|c|c|c|c|c|c|}
\hline SI. No. & Isolate No. & Form & Elevation & Margin & Surface & Opacity & Chromo-genesis \\
\hline 1 & TF1-1a & Irregular & Raised & Entire & Smooth & Opaque & Absent \\
\hline 2 & TF1-1b & Irregular & Flat & Entire & Smooth & Opaque & Absent \\
\hline 3 & TF1-1c & Irregular & Raised & Entire & Smooth & Opaque & Absent \\
\hline 4 & TF1-1d & Irregular & Flat & Undulated & Smooth & Opaque & Absent \\
\hline 5 & TF1-1e & Irregular & Flat & Undulated & Smooth & Opaque & Absent \\
\hline 6 & TF1-1f & Circular & Flat & Entire & Smooth & Opaque & Absent \\
\hline 7 & TF1-2a & Irregular & Raised & Entire & Smooth & Opaque & Absent \\
\hline 8 & TF $1-2 b$ & Irregular & Flat & Entire & Smooth & Glistening & Absent \\
\hline 9 & TF1-2c & Irregular & Raised & Entire & Smooth & Opaque & Absent \\
\hline 10 & TF1-2d & Irregular & Flat & Undulated & Smooth & Opaque & Absent \\
\hline 11 & TF1-2e & Irregular & Flat & Undulated & Smooth & Opaque & Absent \\
\hline 12 & TF1-2f & Circular & Flat & Entire & Smooth & Opaque & Absent \\
\hline 13 & TF1-3a & Irregular & Raised & Entire & Smooth & Opaque & Absent \\
\hline 14 & TF1-3b & Irregular & Flat & Entire & Smooth & Opaque & Absent \\
\hline 15 & TF $1-3 c$ & Irregular & Raised & Entire & Smooth & Opaque & Absent \\
\hline 16 & TF1-3d & Irregular & Flat & Undulated & Smooth & Opaque & Absent \\
\hline 17 & TF $1-3 \mathrm{e}$ & Irregular & Flat & Undulated & Smooth & Glistening & Absent \\
\hline 18 & TF1-3f & Circular & Flat & Entire & Smooth & Opaque & Absent \\
\hline
\end{tabular}


fragments with 1500 bp were observed (Fig. 3). Based on 16S rRNA sequence analysis, endophytic bacteria isolated from Acacia catechu were identified as Bacillus humi. Krishnan et al. (2012) had isolated endophytic bacteria from different papaya varieties and 16S rRNA sequence revealed that Bacillus species were the predominant bacterial endophytes (Fig. 4). The result in the study indicates that distribution of endophytic bacteria mainly depends on environmental conditions such as temperature, humidity, UV irradiation and nutrients in the apoplast and not only on host (Sun et al., 2013). The higher frequency of Bacillus species in Acacia catechu leaves may indicate that they have formed a beneficial association with the plant.

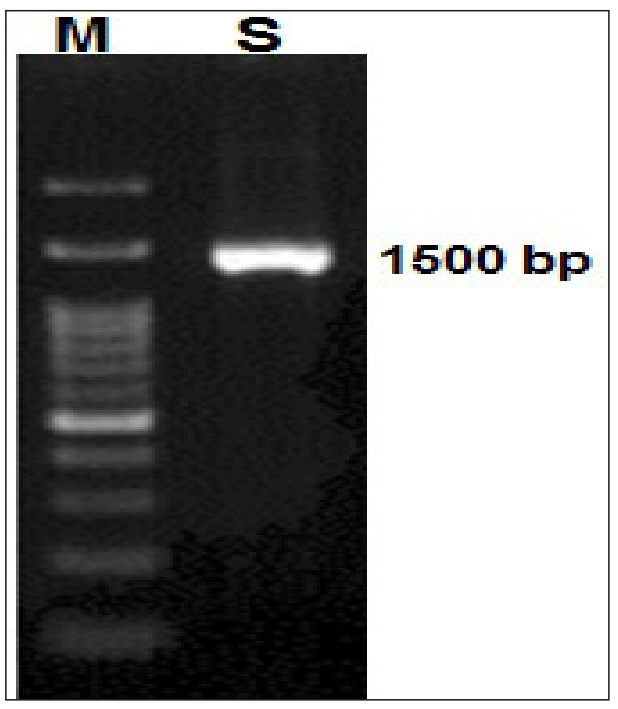

Fig. 3: Agarose gel electrophoresis of $16 \mathrm{~S}$ rRNA gene Polymerase Chain Reaction product of endophytic bacteria isolated from leaves of Acacia catechu. Lane M: 100 bp ladder; Lane S: PCR product

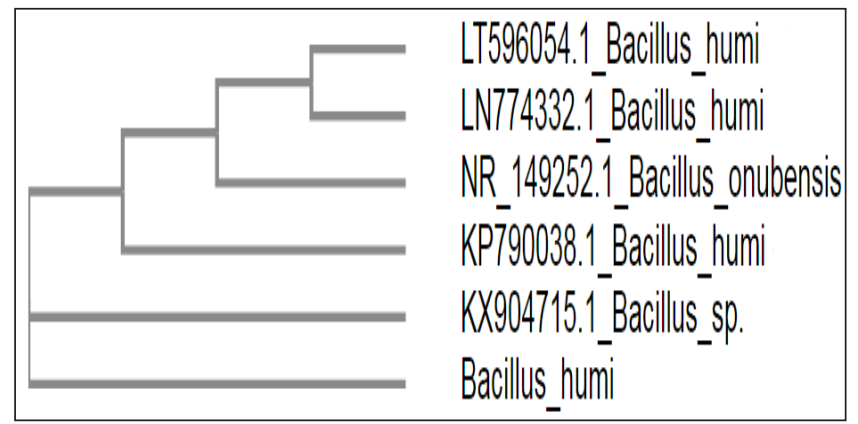

Fig. 4: Construction of Phylogenetic tree

\section{In vitro antibacterial activity of isolated endophytic} bacteria

The endophytic bacteria isolated from Acacia catechu shown antibacterial activity as 80 per cent isolates inhibited growth of Staphylococcus aureus (Fig. 5), 85 per cent of isolates inhibited growth of Salmonella Typhimurium (Fig. 6) and 60 per cent of isolates inhibited growth of Klebsiella pneumoniae (Fig. 7) and no isolates had inhibited growth of Streptococcus pyogenes, Bacillus cereus and Escherichia coli (Fig. 5).

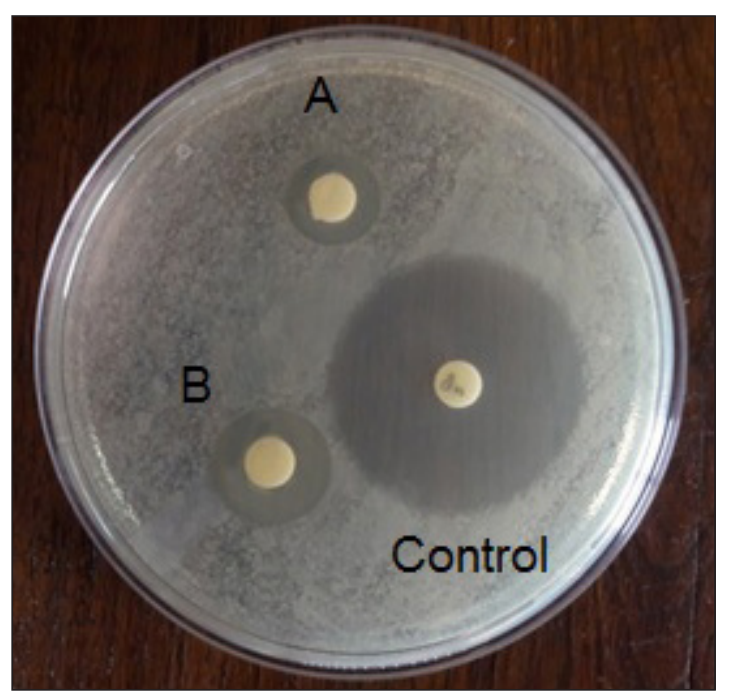

Fig. 5: In vitro antibacterial activity of endophytic bacteria isolated from leaves of Acacia catechu (A, B) against Staphylococcus aureus

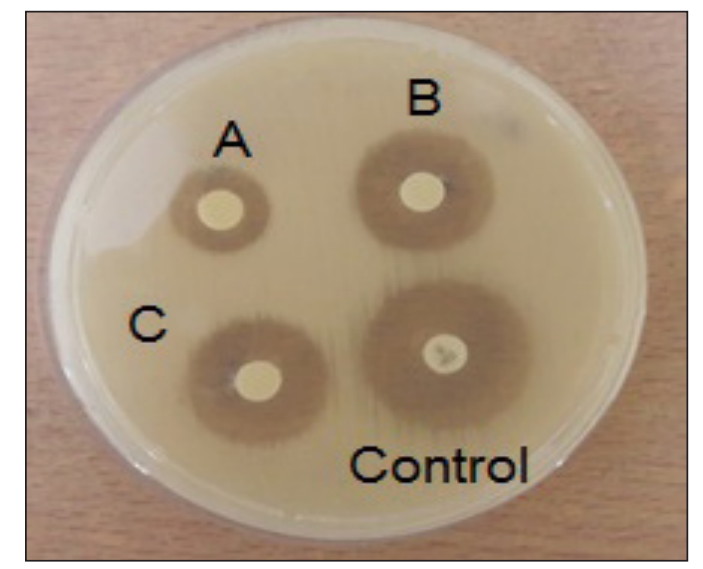

Fig. 6: In vitro antibacterial activity of endophytic bacteria isolated from leaves of Acacia catechu $(\mathrm{A}, \mathrm{B}, \mathrm{C})$ against Salmonella Typhimurium 


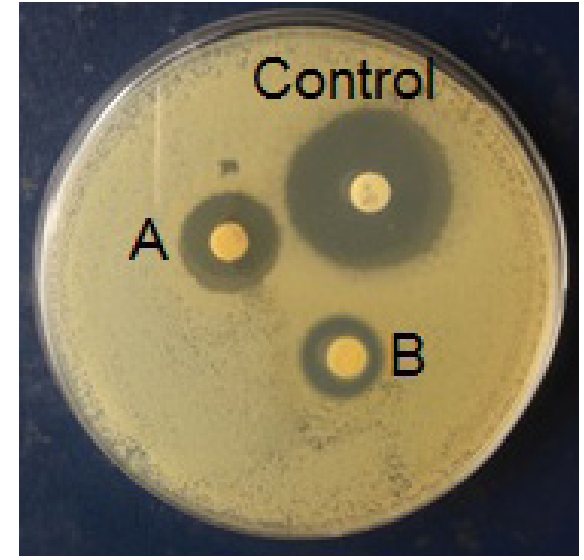

Fig. 7: In vitro antibacterial activity of endophytic bacteria isolated from leaves of Acacia catechu (A, B) against Klebsiella pneumoniae

This antibacterial effect which I have seen in my experimentation may be due to presence of metabolites which suggests that these metabolites of endophytic bacteria might had diffused in the culture medium and suppressed the growth of pathogenic bacteria. The findings of my studies are very similar with the reports of following researchers viz. Roy and Banerjee (2010) had isolated endophytic bacteria from Vinca rosea and one of the isolated endophytes produced potential antimicrobial activity against some selected pathogenic bacteria like Bacillus cereus, Klebsiella pneumoniae, Vibrio cholera, Escherichia coli. Sunkar and Nachiyar (2013) had found antibacterial activity of endophytic bacteria isolated from Brassica olerace $a$ and the isolated endophyte was showing significant antimicrobial activity against Klebsiella pneumoniae NCIM 2883 (20 mm), Staphylococcus aureus ATCC 25923 (25 mm), Escherichia coli ATCC 25922 (13 $\mathrm{mm}$ ) and Salmonella typhi ATCC 6539 (12 mm).

\section{REFERENCES}

Aravamutham, N., Kumar, G., Karthik, L. and Bhaskara Rao, K.V. 2010. In vitro antagonistic activity of soil actinobacteria against multidrug resistant bacteria. Pharmacol Online, 2: 507-551.

Bauer, A.W., Kirby, W.M.M., Sherris, S.C. and Turk, M. 1969. Antibiotic susceptibility testing by a standerized single disc method. Am. J. Clin. Pathol., 45: 493-496.
Edwards, U., Rogall, T., Blocker, H., Emde, M. and Bottger, C. 1989. Isolation and direct complete nucleotide determination of entire genes : Characterization of a gene coding for $16 \mathrm{~S}$ rRNA . Nucleic Acids Res., 17(19): 7843-7853.

Hallmann, J., Hallmann, A., Mahaffee, W.F. and Kloepper, J.W. 1997. Bactetrial endophytes in agriculture crops. Canadian J. Microbiol., 43: 875-914.

Henric, J., Stafseth, J., Stockton, J., John, O. and Newman, T. 1956. A laboratory Manual of Immunology. $3^{\text {rd }}$ Ed., Relnk Book publisher, pp. 4-6.

Kirubaharan, J.J., Paliniswami, K.S., Anubukumar, K. and Mohanasubramaniam. 1999. In vitro studies on antibacterial effect of crude garlic extract on E. coli. Indian Vet. J., 76: 797-799.

Krishnan, P., Bhat, R., Kush, A. and Ravikumar, P. 2012. Isolation and functional characterization of bacterial endophytes from Carica papaya fruits. J. Appl. Microbiol., 113: 308-317.

Mahajan, S., Bakshi, S., Bansal, D. and Bhasin, P. 2014. Isolation and Characterization of Endophytes. Int. J. Latest Scient. Res. Technol., 1: 29-33.

Rosales, E.P., Melendez, L.A., Puente, M.E., Juarez, R.V., Guzman, E.Q., Savin, T.Z. and Bojorquez, E.M. 2017. Isolation and Characterization of endophytic bacteria associated with roots of jojoba (Simmondsia chinensis). Curr. Sci., 112(2): 396-401.

Roy, S. and Banerjee, D. 2010. Isolation of antimicrobial compound by endophytic bacteria from Vinca rosea. Int. J. Curr. Res., 5: 47-51.

Seo, W.T., Lim, W.J., Kim, E.J., Yun, H.D., Lee, Y.H. and Cho, K.M. 2010. Endophytic bacterial diversity in the young raddish and their antimicrobial activity against pathogens. $J$. Korean Soc. Appl. Biochem., 53: 493-503.

Strobel, G., Daisy, B., Castillo, U. and Harper, J. 2004. Natural products from endophytic microorganisms. J. Natural Prod., 67: $257-268$

Sun, H., He, Y., Xiao, Q., Ye, R. and Tian, Y. 2013. Isolation, characterization and antimicrobial activity of endophytic bacteria from Polygonum cuspidatum. African J. Microbiol. Res., 7(16): 1496-1504.

Sunkar, S. and Nachiyar, V. (2013). Isolation and characterization of an endophytic bacterium from Brassica oleracea with potential enzyme and antibacterial activity. Asian $J$. Pharmaceut. Clinic Res., 6(2): 183-187.

Yadav, M., Parle, M., Kadian, R. and Sharma, K. 2014. Phytopharmacology of Acacia catechu willd: A review. World J. Pharmacy Pharmaceut. Sci., 3(11): 1380-1389. 
